\title{
Physiological Characterization of Fungal Inoculum for Biotechnological Remediation of Soils
}

\author{
Nara Ballaminut ${ }^{1 *}$, Kátia Maria Gomes Machado ${ }^{2}$, Luisa Helena dos Santos Oliveira ${ }^{3}$ and \\ Dácio Roberto Matheus ${ }^{3}$ \\ ${ }^{I}$ Núcleo de Pesquisa em Micologia; Instituto de Botânica da Secretaria de Meio Ambiente do Estado de São Paulo; \\ São Paulo - SP - Brasil. ${ }^{2}$ Grupo de pesquisa em Ciências Biológicas - Biotecnologia; Universidade Católica de \\ Santos; Santos - SP - Brasil. ${ }^{3}$ Centro de Engenharia, Modelagem e Ciências Sociais Aplicadas; Universidade \\ Federal do ABC; Santo André - SP - Brasil
}

\begin{abstract}
The aim of this work was to study the bioremediating potential of Lentinus crinitus CCIBt2611 according to the physiological condition of the inoculum. Inoculum was prepared using sugarcane ground husk (C:N 90), at several physiological ages and applied in soil contaminated with pentachlorophenol. The inoculum's potential was assessed by evaluating the mycelium's vigor at soil's colonization, determination of peroxidase and phenoloxidase activities, in vitro degradation of Remazol Brilliant Blue $R$ and in vivo degradation of pentachlorophenol. The results showed that the assessed parameters were relevant to identify the quality of the inoculum. For L. crinitus, 10 day old inoculum showed good soil-colonization speed with significant enzymatic activities, indicating the role of Manganese-dependent peroxidase and laccase in degradation, and efficient degradation of pentachlorophenol.
\end{abstract}

Key words: laccase, manganese-dependent peroxidase, organochlorine degradation, fungal inoculum quality, bioremediation, environmental sanitization

\section{INTRODUCTION}

The xenobiotics degradation by basidiomycete is an oxidative, extracellular and non-specific process and can be understood as a multienzymatic process resulting from the coordinated action of peroxidases, laccases and oxidases (Boyle et al. 1992; Leonowicz et al. 1999). The main ligninolytic enzymes produced by the basidiomycetes directly involved in the degradation of natural polymers are manganesedependent peroxidase (MnP, E.C. 1.11.1.13) and laccases (E.C. 1.10.3.2) (Papinutti et al. 2003; Wesenberg et al. 2003; Rabinovich et al. 2004; Kulikova et al. 2011), Basidiomycetes species from the genus Lentinus have been assessed because of their capacity of degrading recalcitrant compounds such as polyaromatic hydrocarbides (Valentín et al. 2006; Covino et al. 2010), polychlorinated byphenils (Ruiz-Aguilar et al. 2002). L. crinitus CCIBt2611 presented the capacity of mineralizing hexachlorobenzene and pentachlorophenol, as well as reactive textile dyers (Matheus et al. 2000; Matheus et al. 2003; Machado et al. 2005a; Moreira Neto et al. 2009). Therefore, such fungus has been assessed in bioremediation processes for decontamination of soils containing organochlorine compounds (Matheus et al. 2003).

For bioremediation process, the inoculum must be produced in large scale, with the same technology employed in the cultivation of edible mushrooms

*Author for correspondence: nara.ballaminut@ufabc.edu.br 
(Ballaminut and Matheus 2007). The fungal mycelium's colonization capacity of the substrate is the main quality criterion for the inoculum, which is generally employed at the physiological age of 20 days (Bononi 1997, Lamar and White 2001; Matheus 2003). However, the physiological conditions that knowingly enhance fungal inoculum's strength vary according to growth time on solid substrate (Ballaminut and Matheus 2007) and may interfere in the efficiency of degradation of the pollutant present in the soil to be treated. A study on $L$. crinitus cultivated in liquid medium defined both the initial and the exponential growth phase of that fungus; biomass was determined after dry weight, along with ergosterol quantification (Silva et al. 2010). The production of ligninolytic enzymes and their direct or indirect involvement in the xenobiotics-degradation metabolism is well documented in literature (Fragoeiro and Magan 2005; Moreira Neto et al. 2009; Oliveira et al. 2010; Kulikova et al. 2011).

In order to improve the quality parameters used to evaluate the fungal inoculum applied for soil bioremediation, thus optimizing the treatment process, this study aimed to evaluate different times of substrate colonization by Lentinus crinitus CCIBt2611, providing favorable conditions for in vivo degradation of pentachlorophenol in soil, associated with the shorter preparing time of the inoculum.

\section{MATERIALS AND METHODS}

\section{Fungus}

Lentinus crinitus CCIBt2611 was obtained from the Algae, Cyanobacteria and Fungi Culture Collection of the Botanic Institute of São Paulo (CCIBt) and stored in MEA 2\% culture medium at $4^{\circ} \mathrm{C}$.

\section{Cultivation in soil \\ PCP-soil}

Two hundred milligram pentachlorophenol P.A. $\mathrm{kg}^{-1}$ from sandy soil were mixed with commercial plaster (2.5\%), followed by manual homogenization in propylene bag for $15 \mathrm{~min}$. The soil underwent chemical sterilization with methylbromide in sealed chamber for $48 \mathrm{~h}$ (Moreira Neto 2006).

\section{Fungal inoculum}

Ten gram solid substrate with $70 \%$ humidity (dry mass), with C:N ratio adjusted to 90 (92.3\% sugarcane husk, $0.3 \%$ soy flour, $7.4 \%$ soluble amide) was taken in polypropylene bags and sterilized at $121^{\circ} \mathrm{C}$ for $90 \mathrm{~min}$. Five mm-diameter mycelium growth disks (MEA 2\%) were inoculated in the solid substrate in 1:10 proportion (disk : g humid substrate) and incubated at $28^{\circ} \mathrm{C}$ for $5,10,15$ and 20 days. The inoculum age of varying age (T5, T10, T15 and T20) were used.

\section{Cultivation in PCP-soil}

Thirty gram sterilized PCP-soil (dry mass) was added into $250 \mathrm{~mL}$ capacity flasks containing 5.0\% vegetable-oil emulsion and Tween 20 (9:1, p.p.), $10.0 \%$ inoculum (dry mass) of different physiological ages and $15.0 \%$ sterile water. The control-treatment received solid substrate without fungus. The flasks were incubated at $28^{\circ} \mathrm{C}$ for 60 days. Humidity correction was made periodically by gravimetric analysis (Matheus 2003).

\section{Soil-colonization analysis}

The fungal growth in the PCP-soil was analyzed by visual observation. A value was stipulated for each replication according to the soil's percent colonization, judged by six independent observers (Ballaminut and Matheus 2007).

\section{Enzymatic assays}

The enzymatic extracts were obtained by mixing $10 \mathrm{~g}$ soil sample in $30 \mathrm{~mL}$ of $50 \mathrm{~mm}$ sodium acetate ( $\mathrm{pH}$ 4.5) (Ballaminut et al. 2009). The contents were homogenized manually for three minutes followed by mechanical stirring ( 2 hertz) for $1 \mathrm{~h}\left(\mathrm{Tecnal}^{\circledR} / \mathrm{TE}-140\right)$. After settling, the supernatant was separated by filtration $(0.45 \mu \mathrm{m}$ Millipore $^{\circledR}$ ) and used for the enzymatic assays.

Laccase: Laccase was determined through ABTS \{acid 2,2-azine-bis-(3-ethylbenzotiazol-6sulphonic) \} oxidation at $420 \mathrm{~nm}$ (molar extinction coefficient $\left.=36,000 \mathrm{M}^{-1} \mathrm{~cm}^{-1}\right)$. The reacting solution $(1.0 \mathrm{~mL})$ contained $250 \mu \mathrm{L}$ of $50 \mathrm{mM}$ cytrate-phosphate buffer, $\mathrm{pH} 4.0 ; 50 \mu \mathrm{L}$ ultrapure water; $100 \mu \mathrm{L}$ of $5 \mathrm{mM}$ ABTS and $600 \mu \mathrm{L}$ enzymatic extract (Machado and Matheus 2006; Ballaminut et al. 2009). One unit of enzyme corresponded to the enzyme amount to oxide $1 \mu \mathrm{m}$ ABTS per min.

\section{Total peroxidases}

The reaction solution contained the same reagents used for laccases determination, but replacing ultrapure water with $50.0 \mu \mathrm{L}$ of $2 \mathrm{mM} \mathrm{H} \mathrm{H}_{2} \mathrm{O}_{2}$ (Machado and Matheus 2006; Ballaminut et al. 
2009). One unit of enzyme corresponded to the amount of the enzyme required to oxide $1 \mu \mathrm{m}$ ABTS per min. Total peroxidases were given by the difference between the value obtained in the reaction and the previously determined laccase activity (Eggert et al. 1996).

\section{Manganese-dependent peroxidase}

Mn-dependent peroxidase was assayed by phenolred oxidation determined at $610 \mathrm{~nm}$ (Machado and Matheus 2006). The reaction mixture $(1.0 \mathrm{~mL})$ contained $300 \mu \mathrm{L}$ of $0.2 \mathrm{M}$ sodium succinate buffer ( $\mathrm{pH} 4.5$ ), $0.1 \mathrm{M}$ sodium lactate and $0.5 \%$ bovine albumin; $50 \mu \mathrm{L}$ of $2 \mathrm{~mm} \mathrm{MnSO}_{4} ; 100 \mu \mathrm{L}$ of $0.1 \%$ phenol-red; $50 \mu \mathrm{L}$ of $2 \mathrm{~mm} \mathrm{H}_{2} \mathrm{O}_{2}$; and $500 \mu \mathrm{L}$ enzymatic extract. One enzyme unit corresponded to the amount required to oxide 1 $\mu \mathrm{m}$ substrate per min.

$R B B R$ de-coloration: RBBR de-colorization was determined by the decoloratization of Remazol Brilliant Blue R (RBBR) at 592nm according to Machado and Matheus (2006). The reaction mixture contained the same reagents used for the determination of total peroxidases with RBBR $(0.02 \%)$ instead of ABTS. One activity unit was defined as the amount necessary to reduce 0.01 in absorbance after $10 \mathrm{~min}$, using enzymatic extract inactivated by wet heat as control.

\section{Pentachlorophenol in vivo biodegradation}

It was determined through the concentration variation of pentachlorophenol remaining in the soil during cultivation, using as abiotic control the concentration of that residual pollutant in the soil without the fungus.

\section{Extraction of the remaining pentachlorophenol}

The extraction was carried out in sealed $20 \mathrm{~mL}$ flasks containing aliquots of $3.0 \mathrm{~g}$ combined soilsample and fungal inoculum, with $10.0 \mathrm{~mL}$ methanol P.A. The flasks were heated in microwave oven for 16 cycles of $20 \mathrm{~s}$ at $270 \mathrm{~W}$, alternating ice-baths to avoid boiling and loss by volatilization (Andréa et al. 2001 modified). After cooling, the solvent was recovered and $1.0 \mathrm{~mL}$ of each sample was diluted (1:2) in methanol (HPLC grade).

\section{Pentachlorophenol quantification}

The diluted samples were analyzed by HPLC (Varian ProStar ${ }^{\circledR} 215$ ). For pollutant separation, reverse-phase Hipersyl 4.6 x $250 \mathrm{~mm}$ column was used with R - Sil C - $18(10 \mu \mathrm{m})$ and acetonitril: water : acetic acid $(75: 25: 0.125)$ mobile phase (flow rate $0.9 \mathrm{~mL} \cdot \mathrm{min}^{-1}$ ). The detection was made at $254 \mathrm{~nm}$; pentachlorophenol retention time in the chromatographic column was between 7 and 7.4 min after sample injection (Ullah et al. 2000). The pentachlorophenol amount from the extracts was estimated after a previously settled standard curve, where the amounts found were obtained linearregression analysis $\left(y=6000000 x+92782 ; r^{2}=\right.$ 0.999).

\section{Statistical analysis}

Data were assessed using the MiniTab ${ }^{\circledR}$ statistic program version Release 14 . The means were compared through Tukey test, following the analysis of variance (ANOVA) $(\alpha \leq 0.1)$. Percent data were transformed in the following expression, according to Vieira and Hoffmann (1989).

Transformed value $=\operatorname{arcsen}[$ root $(\%$ value $/ 100)]$ Where: arcsen $=$ sine arch and $\%$ value $=$ pentachlorophenol percent recovery.

\section{RESULTS}

Figure 1 shows PCP-soil colonization by $L$. crinitus. The treatments T10, T15 and T20 produced superficial colonization, at first faster, reaching up to $40 \%$ on the $10^{\text {th }}$ day of cultivation.

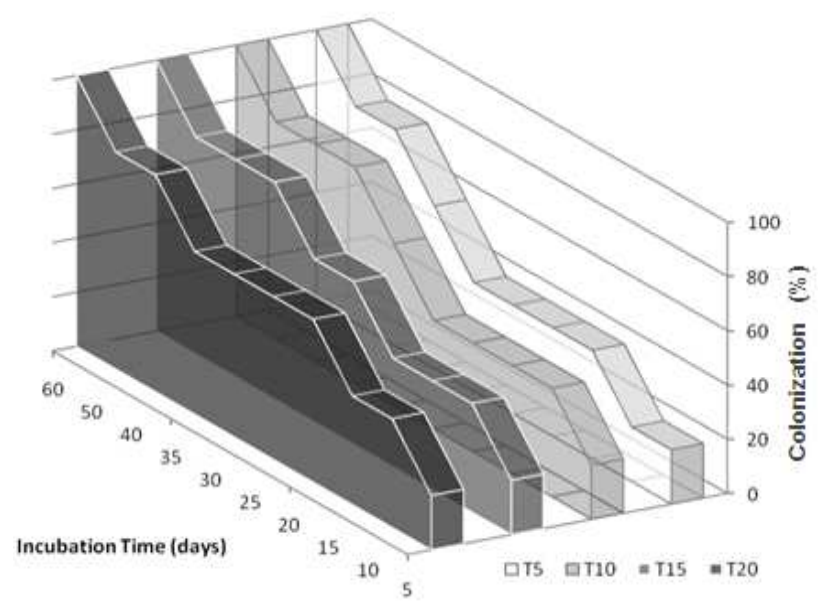

Figure 1 - Colonization of soil contaminated with pentachlorophenol (PCP) by the inoculum of Lentinus crinitus CCIBt2611 at different physiological ages: T5 = 5-day inoculum; T10 = 10-day inoculum; T15 = 15-day inoculum; T20 = 20-day inoculum.

However, after 35 days cultivation, only T10 and T15 showed faster colonization speed, reaching around $80 \%$ colonization, followed by $\mathrm{T} 5$ and 
T20, which reached the same percent colonization after 40 days cultivation. At day 60, the PCP-soil was completely colonized, regardless of the inoculum age.

Figures 2, 3, 4 and 5 show enzymatic activities of laccases, total peroxidases, and RBBR decoloration by $L$. crinitus in PCP-soil after each treatment, T5, T10, T15 and T20, respectively. The enzymatic activities were observed all along incubation (60 days) in PCP-soil independent of the treatment.

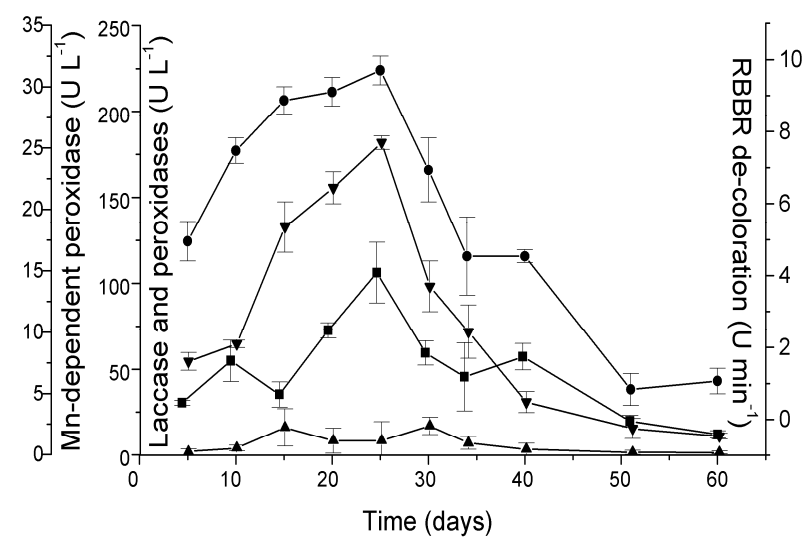

Figure 2 - Enzymatic activities of total peroxidases $(\mathbf{\Lambda})$, Mn-dependent peroxidase (๘), laccase $(\mathbf{\nabla})$, and RBBR de-coloration ( $\bullet$ ) by Lentinus crinitus CCIBt2611, physiological age 5 days (T5), during growth in soil contaminated with pentachlorophenol (error-bars \pm average deviation).

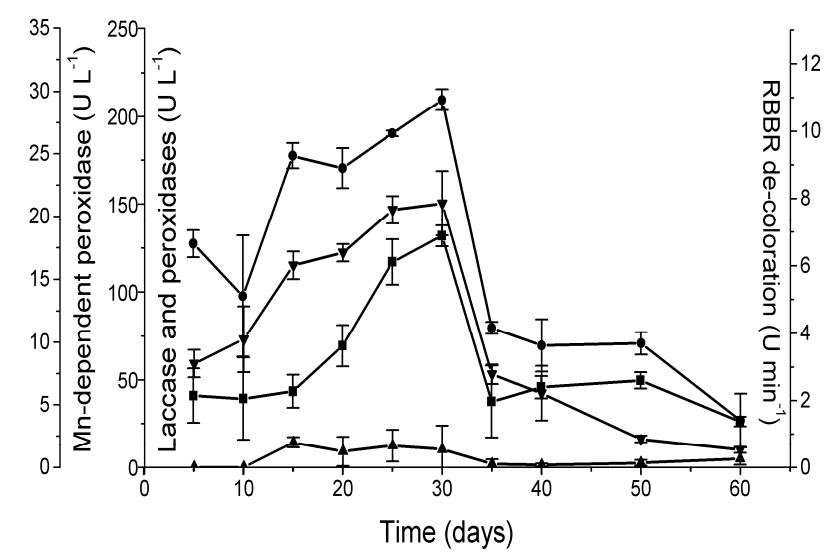

Figure 3 - Enzymatic activities of total peroxidases $(\mathbf{\Lambda})$, Mn-dependent peroxidase ( $\bullet)$, laccase $(\mathbf{\nabla})$, and RBBR de-coloration ( $\bullet$ ) by Lentinus crinitus CCIBt2611, physiological age 10 days (T10), during growth in soil contaminated with pentachlorophenol (error-bars \pm average deviation).

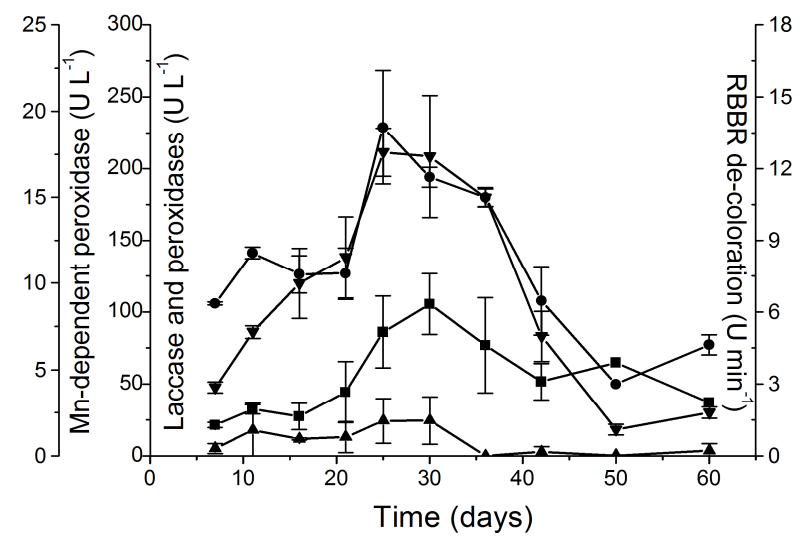

Figure 4 - Enzymatic activities of total peroxidases (৫), Mn-dependent peroxidase (๘), laccase $(\boldsymbol{\nabla})$, and RBBR de-coloration ( $\bullet$ ) by Lentinus crinitus CCIBt2611, physiological age 15 days (T15), during growth in soil contaminated with pentachlorophenol (error-bars \pm average deviation).

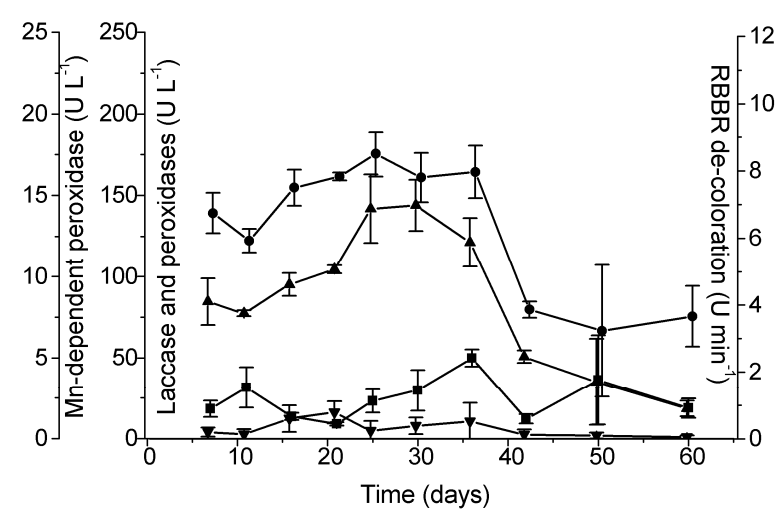

Figure 5 - Enzymatic activities of total peroxidases (₫), Mn-dependent peroxidase (๘), laccase $(\boldsymbol{\nabla})$, and RBBR de-coloration ( $\bullet$ ) by Lentinus crinitus CCIBt2611, physiological age 20 days (T20), during growth in soil contaminated with pentachlorophenol (error-bars \pm average deviation).

Laccase production seemed to be main enzymatic activity in every treatment, presenting a profile similar to RBBR de-coloration's kinetics. The highest levels of laccase activity were observed 15 to 30 days after T10-incubation. Treatments T10 and T20 results maximum laccase activity in 15 days with 150.32 and $143.84 \mathrm{U} \mathrm{L}^{-1}$, respecively. The treatment $\mathrm{T} 10$ also presented higher RBBR de-coloration values, $10.93 \mathrm{U} \mathrm{L}^{-1}$. Among the peroxidases, $\mathrm{Mn}$ dependent peroxidase was highest in $\mathrm{T} 10\left(18.44 \mathrm{U} \mathrm{L}^{-1}\right)$. 
PCP in vivo degradation was maximal on the $5^{\text {th }}$ day of $L$. crinitus cultivation in the PCP-soil in the first treatments (T5, T10 and T15), with only $1.3 \%$ PCP recovery (up to $98.7 \%$ depletion) and no significant difference between the treatments. However, treatment T10 presented the highest degradation rate $\left(\mathrm{y}=277.14 \mathrm{e}^{-0,871 \mathrm{x}}\right)$, as shown in Figure 6. For the $15^{\text {th }}$ day cultivation, no pentachlorophenol recovery was observed in any of the treatments, because the complete degradation occurred on the $5^{\text {th }}$ day (Fig. 7). At the same time, highest activity of Mn-dependent peroxidase was also observed on the $5^{\text {th }}$ day incubation in PCP-soil in the same treatment (Fig. 7). Treatment T10 already presented higher Mndependent peroxidase activity after fungal inoculation in the PCP-soil $\left(53.09 \mathrm{U} \mathrm{L}^{-1}\right)$ as shown in Figure 8.

The data obtained in the degradation of the organic chlorinated was validated through the PCP-soil extraction method efficiency, with 87.26\% recovery of the initial pentachlorophenol concentration $\left(277.139 \pm 28.739 \mathrm{mg} \mathrm{kg}^{-1}\right.$ soil $)$.
Also, pollutant's abiotic losses up to $37 \%$ were observed, out of which the lowest occurred in the treatment $\mathrm{T} 10(3 \%)$.

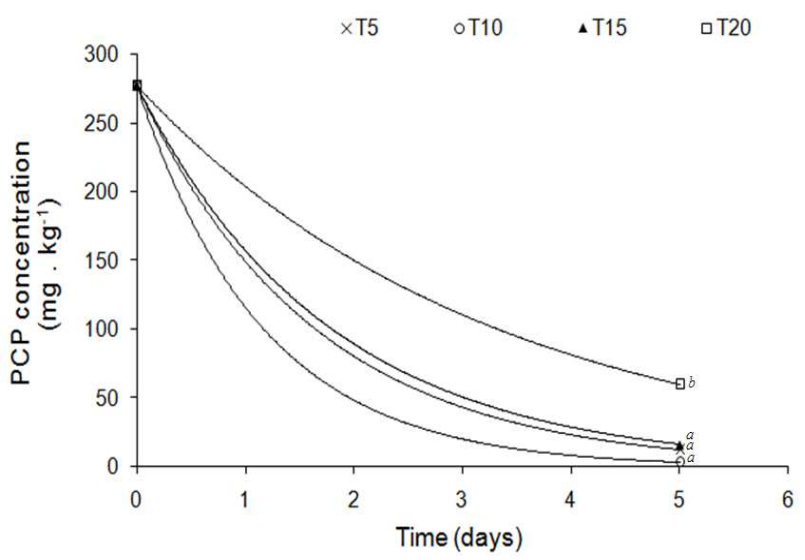

Figure 6 - Residual concentration of pentachlorophenol (PCP) in the soils incubated with Lentinus crinitus CCIBt2611 in treatments $\mathrm{T} 5(\mathrm{y}=$ $\left.277 \mathrm{e}^{-0,56 \mathrm{x}}\right), \mathrm{T} 10\left(\mathrm{y}=277 \mathrm{e}^{-0,87 \mathrm{x}}\right)$, T15 $(\mathrm{y}=$ $\left.277 \mathrm{e}^{-0,61 \mathrm{x}}\right)$ e $\mathrm{T} 20\left(\mathrm{y}=277 \mathrm{e}^{-0,30 \mathrm{x}}\right)$. Equations shows degradation rate (differents letters indicate statistical difference - Tukey Test, $P$ $\leq 0,1)$.
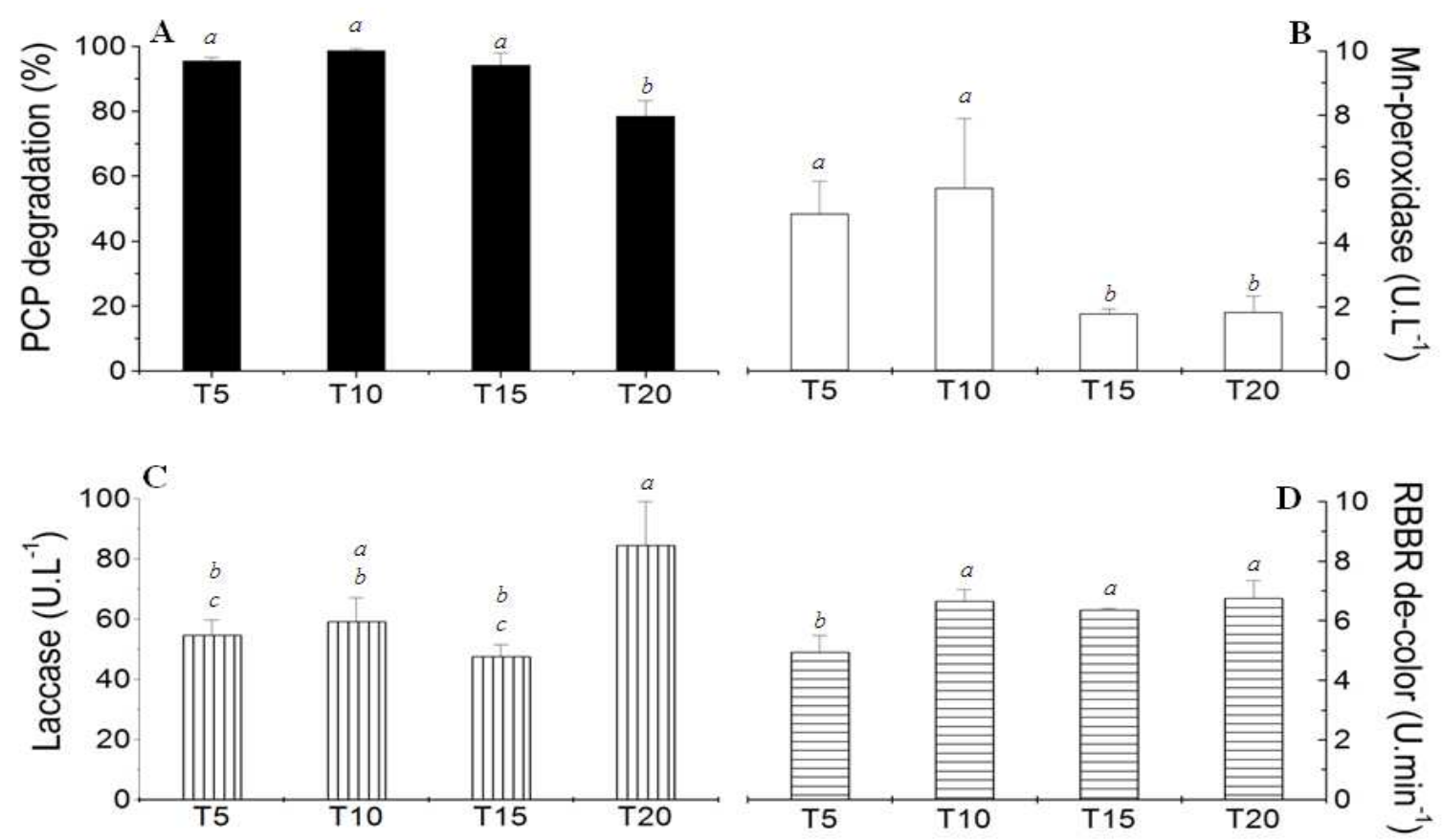

Figure 7 - A) Soil-pentachlorophenol percent decrease ( $\mathbf{a})$; B) Mn-dependent peroxidase's enzymatic activity ( $\square)$; C) laccase's activity ( || $\mid)$; D) RBBR de-coloration (三) in $5^{\text {th }}$ day of cultivation of Lentinus crinitus CCIBt2611, in the different treatments $(\mathrm{T} 5=5$-day inoculum, T10 = 10-day inoculum, T15 = 15-day inoculum, and T20 = 20-day inoculum). (differents letters indicate statistical difference - Tukey Test, $P \leq 0,1)$. 


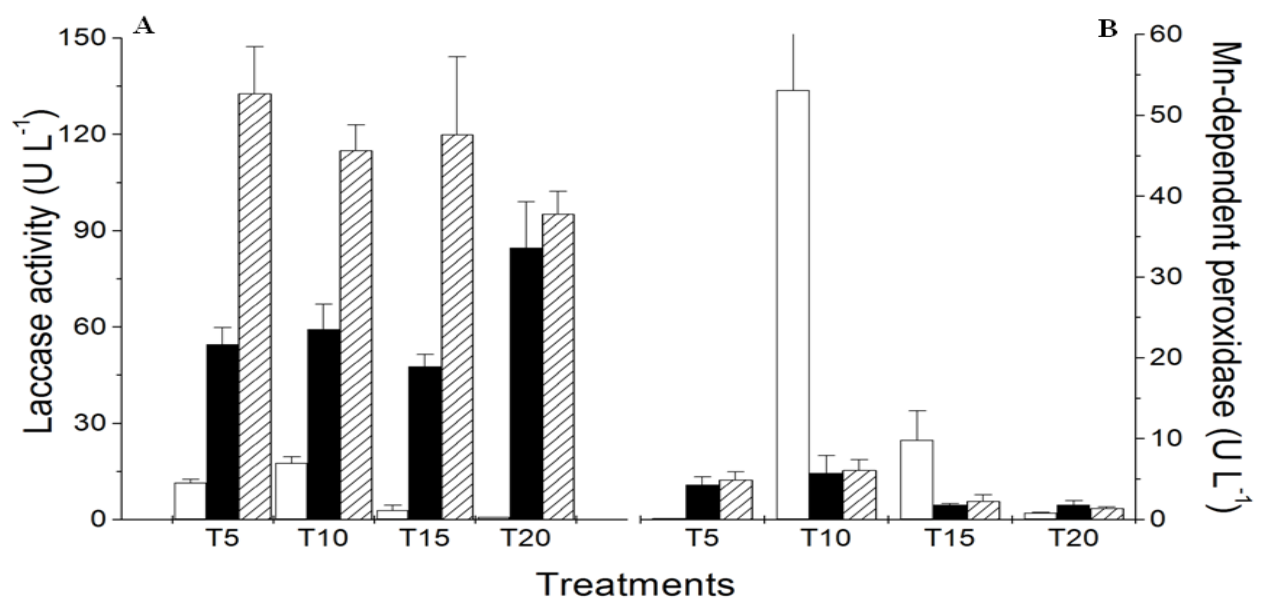

Figure 8 - A) Laccase's enzymatic activities and B) Mn-dependent peroxidase's, both on solid substrate and in the soil. Enzymatic activities on solid substrate at soil-inoculation in the zero days ( $\square), 5^{\text {th }}$ day $(\square)$ and $15^{\text {th }}$ day $(/ / /)$ of soil cultivation, by Lentinus crinitus CCIBt2611, in the differents treatments (T5 = 5-day inoculum, T10 = 10-day inoculum, $\mathrm{T} 15=15$-day inoculum, and T20 = 20-day inoculum). Error bar \pm average deviation.

\section{DISCUSSION}

The analysis of colonization by fungal inoculum can be made either directly through visual analysis, as described in this study, or indirectly through the quantification of the biochemical indicators. In a study employing $L$. crinitus (CCIBt2611) Silva et al. (2010) used as biomass indicator ergosterol, cultivated in the same substrate described in this study, concluding that the exponential growth of that strain occurred after the $7^{\text {th }}$ day of incubation. Corroborating the data from Silva et al. (2010), a slower colonization was observed after employing an under-10-day physiological age inoculum, possibly supporting the use of inocula for a time longer than 7 days incubation, when the growth rate was accelerated. The quick colonization of solid substrates by filamentous fungi, as in the case of PCP-soil, could overestimate fungal colonization when visually observed. That happens because of the extension mode of the hyphae, which initially provide the superficial colonization of the substrate, forming a thin layer of mycelium that only afterwards penetrate the substrate mass (Gowthaman et al. 2001, Ballaminut and Matheus 2007). This was as observed in the inocula assessed (T5, T10, T15 and T20). However, the visual observation of the growth for assessing fungal inocula for application in bioremediation might not be a good evaluation inoculum's quality, if applied exclusively. Thus, to evaluate the quality of the inoculum, other parameters such as enzymatic activities and their correlation with the degradation rates should also be considered.

RBBR de-coloration's kinetics employed to identify the ligninolytic system's total action in the de-coloration of the anthrachinonic colorant showed positive results. The similarity of laccase and RBBR de-coloration enzymatic profile proved the hypothesis that laccase was the main oxidase involved in pentachlorophenol degradation, rendering it an important biotechnological tool, which was also observed by other authors, including in degradation studies (Jeon et al. 2008; Moreira Neto et al. 2009; Cañas e Camarero 2010; Majeau et al. 2010; Niebisch et al. 2010; Gaitan et al. 2011; Ding et al. 2012; Eichlerová et al. 2012; Moldes et al. 2012; Pardo et al. 2012; Ueda et al. 2012; Janusz et al. 2013; Manavalan et al. 2013).

Laccase production, with concomitant Mndependent peroxidase production showed that such enzymatic activities might be involved in the in vivo pentachlorophenol degradation under the assessed conditions, since the highest enzymatic activities in the PCP-soil were observed in the treatments with the highest degradation rates. Furthermore, the Mn-dependente peroxidase data in T10, along with the degradation rates, indicated peroxidase as the main involved in the degradation. The results suggested the relevance of the enzymatic levels, especially for the 
peroxidases present in the inoculum soon after its inoculation in the soil on the quality of the inoculum to be employed.

The capacity of basidiomycetes to degrade chlorophenols, including pentachlorophenol as already reported in literature (Okeke et al. 1997; Ullah et al. 2000; Seradati et al. 2003; Machado et al. 2005a; Soares et al. 2011) was proved here. There are difficulties to use the concentrations above $200 \mathrm{mg} \mathrm{kg}^{-1}$ pentachlorophenol, given the basidiomycetes' sensibility to the pollutant (Leontievsky et al. 2001; Ahn et al. 2002; Walter et al. 2004). Hence, the use of $L$. crinitus CCIBt2611 could be promising as it demonstrated efficacy in the treatment of pentachlorophenol in the same concentration range. Lamar and Dietrich (1990) reported up to $91 \%$ pentachlorophenol decrease after using Phanerochaete chrysosporium at concentrations between 250 and $400 \mathrm{mg} \mathrm{kg}^{-1}$ along 6.5 weeks. In a study with $L$. crinitus CCIBt2611, Machado et al. (2005b) observed the capacity of such basidiomycete in degrading pentachlorophenol at much higher concentrations (around 1,400 $\mathrm{mg} \mathrm{kg}^{-1}$ soil), showing the elevated resistance, associated with the rapidity of the fungus to the tested pollutant.

Dzul-Puc et al. (2005), in a study with $P$. chrysosporium in sugarcane husk and pine seraglio estimated the influence of physiological age and substrate on benzo $(\alpha)$ pyrene degradation, concluding that the removal of the contaminant was most efficient when the inoculum age was 5days, which was similar for $L$. crinitus in this work. Some authors have suggested against the use of a too young inoculum in field applications, as the colonization of the contaminated soil would be much slower and hinder the colonization because of the little mycelium biomass present in inoculum (Schmidt et al. 2005; Walter et al. 2005). Similar results were found in this study, which showed 10-days inoculum as the best.

Inocula produced in alginate pellets solid substrate were tested by Lestan and Lamar (1996), who observed that such inocula took up to 8 days for complete colonization, yet, remaining strong enough for their use in the soil, without modifications in their mechanic consistency. In such condition, the fungi removed around 80 to $90 \%$ pentachlorophenol in four weeks, confirming their efficiency and supporting the use of younger inocula. Considering this, the young inocula studied here showed degradation above $90 \%$ after a much shorter time (5 days cultivation), without pellet possibly favoring degradation in a field scale. The abiotic losses were comparable to those observed in the present study (Lamar and Dietrich 1992; Lamar et al. 1994; Matheus et al. 2000; Machado et al. 2005b).

Table 1 showed 11 criteria assessed in the present study that could help selecting the best condition for the cultivation of $L$. crinitus for its use in the bioremediation of soils contaminated with pentachlorophenol. Evidently the best treatment was 10-day physiological age inoculum (T10) satisfying at least $80 \%$ of the quality criteria proposed. Thus, unlike what is preconized (at least 20 days), the biological treatment can employ younger inocula, optimizing their production for biotechnological application.

Table 1 - Qualitative criteria for the evaluation of fungal inoculum produced on solid substrate, where $\mathrm{T} 5=$ treatment with 5-day inoculum, T10 = treatment with 10-day inoculum, T15 = treatment with 15 -day inoculums, and T20 = treatment with 20-day inoculum.

\begin{tabular}{|c|c|c|c|c|}
\hline \multirow{2}{*}{ Qualitative criteria } & \multicolumn{4}{|c|}{ Treatments } \\
\hline & T5 & T10 & T15 & $T 20$ \\
\hline 1. Higher laccase activity in the inoculum at soil-aplication & & $\mathrm{x}$ & & \\
\hline 2. Higher Mn-dependent peroxidase in the inoculum at soil-aplication & & $\mathrm{x}$ & & \\
\hline 3. Inoculum with more biomass at soil-cultivation & & $\mathrm{x}$ & $\mathrm{x}$ & $\mathrm{x}$ \\
\hline 4. Higher laccase activity in the $5^{\text {th }}$ day of soil cultivation & & $\mathrm{x}$ & & $\mathrm{x}$ \\
\hline 5. Higher Mn-dependent peroxidase in the $5^{\text {th }}$ day of soil cultivation & $\mathrm{x}$ & $\mathrm{x}$ & & \\
\hline 6. Higher RBBR de-coloration in the $5^{\text {th }}$ day of soil cultivation & & $\mathrm{x}$ & $\mathrm{x}$ & $\mathrm{x}$ \\
\hline 7. Higher laccase activity during soil-cultivation & & & $\mathrm{x}$ & \\
\hline 8. Higher Mn-dependent peroxidase activity during soil-cultivation & $\mathrm{x}$ & $\mathrm{x}$ & & \\
\hline 9. Higher RBBR de-coloration during soil-cultivation & & & $\mathrm{x}$ & \\
\hline 10. Faster soil-colonization & & $\mathrm{x}$ & $\mathrm{x}$ & $\mathrm{x}$ \\
\hline 11. Higher pentachlorophenol percent degradation & $\mathrm{x}$ & $\mathrm{x}$ & $\mathrm{x}$ & \\
\hline
\end{tabular}




\section{ACKNOWLEDGEMENT}

Financial support by the Rhodia of Brazil and Foundation for the Development of Agricultural Research.

\section{REFERENCES}

Ahn MY, Dec J, Kim J, Bollag JM. Treatment of 2,4dichlorophenol polluted soil with free and immobilized laccase. J Environ Qual. 2002; 31: 1509-1515.

Andréa MM, Papini S, Nakagawa LE. Optimization microwave-assisted solvent extraction of pesticides from soil. J Environ Sci Health. 2001; B36 (1): 8793.

Ballaminut N, Matheus DR. Characterization of fungal inoculum used in soil bioremediation. Braz $J$ Microbiol. 2007; 38: 248-252.

Ballaminut N, Yamanaka R, Machado KMG. Interference of a commercial catalase preparation in laccase and peroxidase activities. Braz Arch Biol Technol. 2009; 52(5): 1193-1198.

Bononi VLR. Biodegradation of organochlorine pesticides in soil by basidiomycetes lignocellulolytic. In: Melo IS, Azevedo JL (ed) Environmental Microbiology. Jaguariúna: Embrapa - CNPMA, 1997. pp. 438.

Boyle CD, Kropp BR, Reid ID. Solubilization and mineralization of lignin by white rot fungi. Appl Environ Microbiol. 1992; 58(10): 3217-3224.

Cañas AI, Camarero S. Laccases and their natural mediators: biotechnological tools for sustainable ecofriendly processes. Biotechnol Adv. 2010; 28: 694705.

Covino S, Svobodová K, Kresinová Z, Petruccioli M, Federici $\mathrm{F}$, D'Annibale $\mathrm{A}$, et al. In vivo and in vitro polycyclic aromatic hydrocarbons degradation by Lentinus (Panus) tigrinus CBS 577.79. Bioresource Technol. 2010; 101: 3004-3012.

Ding Z, Peng L, Chen Y, Zhang L, Gu Z, Shi G, et al. Production and characterization of thermostable laccase from the mushroom, Ganoderma lucidum, using submerged fermentation. Afr J Microbiol Res. 2012; 6(6): 1147-1157.

Dzul-Puc JD, Esparza-García F, Barajas-Aceves M, Rodríguez-Vaáquez R. Benzo[ $\alpha$ ]pyrene removal from soil by Phanerochaete chrysosporium grown on sugarcane bagasse and pine sawdust. Chemosphere. 2005; 58:1-7.

Eggert C, Temp U, Eriksson KEL. The ligninolytic system of the white rot fungus Pycnoporus cinnabarinus: purification and characterization of the laccase. Appl Environ Microbiol. 1996; 62(4): 11511158.
Eichlerová I, Snajdr J, Baldrian P. Laccase activity in soils: considerations for the measurement of enzyme activity. Chemosphere. 2012; 88: 1154-1160.

Fragoeiro S, Magan N. Enzimatic activity, osmotic stress and degradation of pesticide mixtures in soil extract liquid broth inoculated with Phanerochaete chrysosporium and Trametes versicolor. Environ Microbiol. 2005; 7(3): 348-355.

Gaitan IJ, Medina SC, González JC, Rodríguez A, Espejo AJ, Osma JF, et al. Evaluation of toxicity and degradation of a chlorophenol mixture by the laccase produced by Trametes pubescens. Bioresource Technol. 2011; 102: 3632-3635.

Gowthaman MK, Krishna C, Moo-Young M. Fungal solid state fermentation - an overview. In: Khachatourians GG, Arora DK. (ed) Agriculture and Food Production: Applied Mycology and Biotechnology. Amsterdam: Elsevier Science BV; 2001. pp. 305-352.

Janusz G, Kucharzyk KH, Pawlik A, Staszczak M, Paszczynski A. Fungal laccase, manganese peroxidase and lignin peroxidase: Gene expression and regulation. Enzyme Microbiol Technol. 2013; 52(1): 1-12.

Jeon JR, Murugesan K, Kim YM, Kim EJ, Chang YS. Synergistic effect of laccase mediators on pentachlorophenol removal by Ganoderma lucidum laccase. Appl Microbiol Biotechnol. 2008; 81: 783 790.

Kulikova NA, Klein OI, Stepanova EV, Koroleva OV. Use of basidiomycetes in industrial waste processing and utilization technologies: fundamental and applied aspects (Review). Appl Biochem Microbiol. 2011; 47(6): 565-579.

Lamar RT, Davis MK, Dietrich DM, Glaser JA. Treatment of a pentachlorophenol and creosotecontaminated soil using the lignin-degrading fungus Phanerochaete sordida: a field demonstration. Soil Biol Biochem. 1994; 26(12):1603-1611.

Lamar RT, Dietrich DM. 1990. In situ depletion of pentachlorophenol from contaminated soil by Phanerochaete chrysosporium. Appl Environ Microbiol. 1990; 56(10): 3093-3100.

Lamar RT, Dietrich DM. Use of lignin-degrading fungi in the disposal of pentachlorophenol-treated wood. $J$ Ind Microbiol. 1992; 9: 181-191.

Lamar RT, White RB. Micoremediation - commercial status and recent developments. In: Glenn VSM, Ong JSK, Leeson A (ed) Bioremediation of energetics, phenolics and polycyclic aromatic hydrocarbons. San Diego: Battelle Press; 2001. pp 263-278.

Leonowicz A, Matuszewska A, Luterek J, Ziegenhagen D, Wojtás-Wasilewska M, Cho N, et al. Review: biodegradation of lignin by white rot fungi. Fungal Genet Biol. 1999; 27: 175-185. 
Leontievsky AA, Myasoedova NM, Baskunov BP, Golovleva LA, Bucke C, Evans CS. Transformation of 2,4,6-trichlorophenol by free and immobilized fungal laccase. Appl Microbiol Biotechnol. 2001; 57: 85-91.

Lestan D, Lamar RT. Development of fungal inocula for bioaugmentation of contaminated soils. Appl Environ Microbiol. 1996; 62(6): 2045-2052.

Machado KMG, Matheus DR, Bononi VLR. Ligninolytic enzymes production and Remazol Brilliant Blue $\mathrm{R}$ decolorization by tropical brazilian basidiomycetes fungi. Braz J Microbiol. 2005a; 36: 246-252.

Machado KMG, Matheus DR, Monteiro RTR, Bononi VLR. Biodegradation of pentachlorophenol by tropical basidiomycetes in soils contaminated with industrial residues. World J Mircrobiol Biotechnol. 2005b; 21: 297-301.

Machado KMG, Matheus DR. Biodegradation of Remazol Brilliant Blue R by ligninolytic enzymatic complex produced by Pleurotus ostreatus. Braz J Microbiol. 2006; 37: 468-473.

Majeau JA, Brar SK, Tyagi RD. Laccases for removal of recalcitrant and emerging pollutants. Bioresource Technol. 2010; 101: 2331-2350.

Manavalan T, Manavalan A, Thangavelu KP, Heese K. Characterization of optimized production, purification and application of laccase from Ganoderma lucidum. Biochem Eng J. 2013; 70: 106114.

Matheus DM, Bononi VLR, Machado KMG, Silva RR, Rodrigues TA. Growing basidiomycetes in bioreactors to be applied to bioremediation of HCB in soil. In: Magar VS, Kelley ME (ed) In Situ and OnSite Bioremediation. Orlando: Battelle Press. 2003; Paper G5.

Matheus DR, Bononi VLR, Machado KMG. Biodegradation of hexachlorobenzene by basidiomycetes in soil contaminated with industrial residues. World J Microbiol Biotechnol. 2000; 16(5): 415-421.

Matheus DR. Optimization of biodegradation of HCB by basidiomycetous fungi in soils contaminated with industrial waste [Thesis]. São Paulo: Universidade Estadual Paulista; 2003.

Moldes D, Fernández-Fernández M, Sanromán MA. Role of laccase and low molecular weight metabolites from Trametes versicolor in dye decolorization. The Scientific World J. 2012; 1-9.

Moreira Neto SL, Matheus DR, Machado KMG. Influence of $\mathrm{pH}$ on the growth, laccase activity and RBBR decolorization by tropical basidiomycetes. Braz Arch Biol Technol. 2009; 52(5): 1075-1082.
Moreira Neto SL. Enzimas ligninolíticas produzidas por Psilocybe castanella CCB444 em solo contaminado com hexaclorobenzeno [Dissertation]. São Paulo: Instituto de Botânica da Secretaria do Meio Ambiente do estado de São Paulo; 2006.

Niebisch CH, Malinowski NK, Schadeck R, Mitchell DA, Kava-Cordeiro V, Paba J. Decolorization and biodegradation of reactive blue 220 textile dye by Lentinus crinitus extracellular extract. J Hazard Mater. 2010; 180: 316-322.

Okeke BC, Paterson A, Smith JE, Watson-Craik IA. Comparative biotransformation of pentachlorophenol in soils by solid substrate cultures of Lentinula edodes. Appl Microbiol Biotechnol. 1997; 48: 563569.

Oliveira LHS, Barreto MB, Vitalli VMV, Machado KMG, Matheus DR. Decolorization of synthetic dyes by basidiomycetes Brazilian tropical. Natur. 2010; 33: 85-99.

Papinutti VL, Diorio LA, Forchiassin F. Production of laccase and manganese peroxidase by Fomes sclerodermeus grown on wheat bran. $J$ Ind Microbiol Biotechnol. 2003; 30: 157-160.

Pardo I, Vicente AI, Mate DM, Alcalde M, Camarero S. Development of chimeric laccases by directed evolution. Biotechnol Bioeng. 2012; 109: 2978-2986.

Rabinovich ML, Bolobova AV, Vasilchenco LG. Fungal decomposition of natural aromatic structures and xenobiotics: a review. Appl Biochem Microbiol. 2004; 40(1): 1-17.

Ruiz-Aguilar GML, Fernández-Sánchez JM, Rodríguez-Vázquez R, Poggi-Varaldo $\mathrm{H}$. Degradation by white-rot fungi of high concentrations of PCB extracted from a contaminated soil. $A d v$ Environ Res. 2002; 6: 559-568.

Schmidt KR, Chand S, Gostomski PA, Boyd-Wilson $\mathrm{KSH}$, Ford C, Walter M. Fungal inoculum properties and its effect on growth and enzyme activity of Trametes versicolor in soil. Biotechnol Prog. 2005; 21: 377-385.

Seradati MR, Keshavarz T, Leontievsky AA, Evans CS. Transfomation of high concentrations of chlorophenols by the white-rot basidiomycete Trametes versicolor immobilized on nylon mesh. Eletronic J Biotechnol. 2003; 6(2): 104-114.

Silva RR, Corso CR, Matheus DR. Effect of culture conditions on the biomass determination by ergosterol of Lentinus crinitus and Psilocybe castanella. World J Microbiol Biotechnol. 2010; 26(5): 841-846.

Soares IA, Flores AC, Mendonça MM, Barcelos RP, Baroni S. Fungi in bioremediation of degraded areas. Arq Inst Biol. 2011; 78(2): 341-350. 
Ueda M, Shintani K, Nakanishi-Anjyuin A, Nakazawa M, Kusuda M, Nakatani F, et al. A protein from Pleurotus eryngii var. tuoliensis C.J. Mou with strong removal activity against the natural steroid hormone, estriol: purification, characterization, and identification as a laccase. Enzyme Microb Technol. 2012; 51: 402-407.

Ullah MA, Bedford CT, Evans CS. Reactions of pentachlorophenol with laccase from Coriolus versicolor. Appl Microbiol Biotechnol. 2000; 53: 230234.

Valentín L, Feijoo G, Moreira MT, Lema JL. Biodegradation of polycyclic aromatic hydrocarbons in forest and salt marsh soils by white-rot fungi. Int Biodeterior Biodegrad. 2006; 58: 15-21.
Vieira S, Hoffmann R. Estatística Experimental. Editora Atlas. São Paulo; 1989.

Walter M, Boul L, Chong R, Ford C. Growth substrate selection and biodegradation of PCP by New Zealand white-rot fungi. J Environ Manag. 2004; 71: 361-369.

Walter M, Boyd-Wilson KB, Boul L, Ford C, McFadden D, Chong B, et al. Field-scale bioremediation of pentachlorophenol by Trametes versicolor. Int Biodeterior Biodegrad. 2005; 56: 5157.

Wesenberg D, Kyriakides I, Agathos SN. White-rot fungi and their enzymes for the treatment of industrial dye effluents. Biotechnol Adv. 2003; 22: 161-187.

Received: June 14, 2013; Accepted: March 11, 2014. 